Fakultas Pertanian dan Bisnis Universitas Kristen Satya Wacana Jl. Diponegoro 52-60 SALATIGA 50711 - Telp. 0298-321212 ext 354 email: jurnal.agric@adm.uksw.edu, website: ejournal.uksw.edu/agric

\title{
ANALYSIS OF SECONDARY METABOLITES OF CALLUS OF RAMBUTAN Nephelium lappaceum $\mathrm{L}$
}

\section{ANALISIS METABOLIT SEKUNDER DARI KALUS RAMBUTAN Nephelium lappaceum $\mathrm{L}$}

\author{
${ }^{1 *}$ Fahrauk Faramayuda1*, ${ }^{2,3}$ Elfahmi and ${ }^{1}$ Weni Widy Astuti \\ ${ }^{1}$ Faculty of Pharmacy, Jenderal Achmad Yani University (UNJANI), Cimahi, West Java, Indonesia, 40532. \\ Email: ramayuda,f@gmail.com \\ ${ }^{2}$ School of Pharmacy, Bandung Institute of Technology (ITB), Bandung, West Java, Indonesia, 40132. \\ Tel / Fax+62-22-6629821.*Email: elfahmi@gmail.com, \\ ${ }^{3}$ Biosceinces and Biotechnology Research Center, Bandung Institute of Technology (ITB), Bandung, \\ West Java, Indonesia, 40132
}

Diterima: 29 Januari 2021, disetujui 10 Mei 2021

\begin{abstract}
ABSTRAK
Tanaman rambutan (Nephelium lappaceum L.) Merupakan salah satu anggota famili Sapindaceae. Tanaman rambutan merupakan salah satu bahan alami yang berpotensi untuk dikembangkan sebagai obat tradisional. Kulit rambutan mempunyai potensi aktivitas antioksidan dan antikanker yang baik. Buah rambutan tidak tumbuh setiap saat maka perlu upaya untuk memproduksi zat aktif dalam rambutan, salah satunya dengan menggunakan teknik kultur jaringan tanaman. Penggunaan variasi medium dan hormone yang tepat pada konsentrasi yang tepat merupakan kunci sukses kultur jaringan. Eksplan yang berasal dari daun rambutan ditanam secara tepat pada media padat Murashige dan Skoog (MS) dan Woddy Plant Medium (WPM) yang mengandung Indole-3-Butric Acid (IBA) dan Kinetin. Setelah 7 hari kalus disubkultur, kemudian setelah 35 hari kalus subkultur dikumpulkan dan dikeringkan. Kalus kering dan daun rambutan (Wlid type) dimaserasi dengan n-heksan, etilasetat dan etanol, kemudian ekstrak pekat diaplikasikan pada plate silika gel GF 254 dengan fasa gerak Toluen-Aseton (7:3) dan n-heksan-EtilAsetat (3: 7). Hasil penelitian menunjukkan bahwa konsentrasi IBA 2 ppm dan kinetin 3 ppm merupakan kombinasi terbaik karena menghasilkan kalus. Hasil Kromatografi lapis tipis (KLT) daun rambutan dengan kultur jaringan tanaman mengandung flavonoid dan triterpenoid. Hasil penelitian ini memberikan informasi baru mengenai induksi kalus rambutan dan bisa menjadi dasar produksi metabolit aktif dalam rambutan dengan pengembangan ke arah kultur suspensi sel.
\end{abstract}

Kata kunci: tanaman rambutan, kultur jaringan tanaman, pertumbuhan hormonal, kromatografi lapis tipis. 


\begin{abstract}
Rambutan plant (Nephelium lappaceum L.) is a member of the Sapindaceae family. The rambutan plant is one of the natural ingredients that can be developed as traditional medicine. Rambutan peel has the potential for good antioxidant and anticancer activity. Rambutan fruit does not growevery time it needs efforts to produce the active substance in rambutan, using plant tissue culture techniques. The use of the correct variety of mediums and hormones at the right concentration is the key to thriving tissue culture. Explants derived from rambutan leaves were planted precisely on solid media Murashige and Skoog (MS) and WoddyPlant Medium (WPM) containing Indole-3-Butyric Acid (IBA) and Kinetin. After seven days, the callus was subcultured, then after 35 days, the subculture callus was collected and dried. Dry callus and rambutan leaves (Wild type) were macerated with n-hexane, ethyl acetate, and ethanol. The concentrated extract was then applied to a GF 254 silica gel plate with the mobile phase Toluene-Acetone (7: 3) and n-hexane-EthylAsetate (3: 7). The results showed that the concentration of IBA 2 ppm and kinetin three ppm was the best combination because it produced callus. TLC results of rambutan leave with plant tissue culture containing flavonoids and triterpenoids. This study provides new information regarding the induction of rambutan callus and can become the basis for producing active metabolites in rambutan with cell suspension culture development.
\end{abstract}

Keywords: rambutan plants, plant tissue culture, hormonal growth, thin layer chromatography.

\section{INTRODUCTION}

Rambutan (Nephelium lappaceum L.), belonging to the Sapindaceae family relatives with lychees and longan, are traditional plants used for the treatment of various diseases, including the skin of the fruit for overcome dysentery and fever, bark to overcome thrush,. (Dalimarta, 2003). Rambutan belongs to the Sapindacea family (Cronquist, 1981; Ria, 1994), contains carbohydrates, protein, calcium, vitamin C ( $\mathrm{Ria}, 1994)$, iron, phosphorus, and fat (Hariana, 2006). The fruit's skin contains flavonoids, tannins, and saponins. Phenolic compounds have been identified in rambutan fruit skin, namely ellagic acid, corilagine, and geraniin, frommethanolextract of rambutan fruit (Thitilertdecha et al., 2010). Rambutan seeds contain fat and polyphenols. rambutan seeds give positive results on the flavonoid compounds. The leaves contain tannins and saponins. The bark contains tannins, saponins, flavonoids, pectic, and iron (Dalimarta, 2003). Based on previous research, these phenolic compounds have the potential as anticancer (Chen, et al.,
2015; Zhang et al., 2014; Strati, et al., 2009). cells. The mechanism of induction of apoptosis from Elagic Acid is associated with a decrease in ATP production, where ATP is very important for cancer cells' survival (Losso, et al., 2004). Corilagin compound has the potential as an anticancer (Jia et al., 2013; Okabe et al., 200; Gambari et al., 2014; Okabe et al., 200; Kashiwada et al., 1992; Li et al., 2013).

Efforts to increase the phenolic compounds that are efficacious as anticancer in the skin of rambutan fruit need to be done with plant tissue culture techniques. Plant tissue culture is a method or technique for isolating plant tissues, organs, cells, and protoplasts, which we often call explants, and grow them in the growth media aseptic so that the explant can grow and develop. Usagetissueculturein thepharmaceutical field is to increase metabolite levels secondary active. Plant propagation through tissue culture hasseveral uniqueadvantages: rapid multiplication of clones, controlled environment, having the same genetic makeup as its mother, increasing the number of thorny plants to duplicate in 
vegetative ways (Zulkarnain, 2009). Growth regulators are organic compounds that are not nutrients or nutrients, which in small amounts can support or promote, inhibit or inhibit and can change the process of plant physiology (Abidin dan Zainal, 1993).

In this study, rambutan leaves were used as explants with media artificial, namely Murishage and Skoog (MS) and the Woody Plant Medium (WPM) media. Growth regulators (ZPT) are also used, which will affect growth and morphogenesis in the cell, tissue, and organ culture, namelyincluding IBA(3-indolebuthylacetic acid), 2,4D (2,4-dichlorophenoxyacetic acid) and NAA (1-naphthyl acetic acid) and kinetin. Then do it tothe analysis of secondary metabolite compounds of rambutan leaves by chromatography method Thin Layer. This study expects to know the growth-regulating substances, which are useful for callus induction, and the production of secondary metabolites has activity as medicine from rambutan leaves.

\section{MATERIALAND METHODS}

\section{Collection of Rambutan}

Plant material obtained from rambutan plantations in the Subang area of West Java

\section{Rambutan Leaf Tissue Culture}

\section{Space and Equipment Sterilization}

Laminar airflow (LAF) is cleaned using 96\% alcohol. The tools to be used are sterilized by autoclave at a temperature of $121^{\circ} \mathrm{C}$ for 15 minutes.

\section{Sterilization and Preparation Media}

The media and distilled water used first are sterilized in anautoclave. Distilled water sterilized in an autoclave for 15 minutes at $121^{\circ} \mathrm{C}$. Culture media, the one to be used, is sterilized in an autoclave at the same temperature and pressure for 15 minutes. Basic media uses Murashige-Skoog (MS) media and Woddy Plant Medium (WPM).

IBA (Indole-3 Butyric acid) and kinetin as growth regulators are used in various concentrations of $2 \mathrm{ppm}$ and $3 \mathrm{ppm}$. The concentration of growth regulator used in MS and Woddy Plant media IBA: Kinetin (2 ppm: $3 \mathrm{ppm})$. The media is adjusted to $\mathrm{pH} 5.6-5.8$. Media was sterilized by using an autoclave at a temperature of $121 \mathrm{oC}$ for 15 minutes.

\section{Optimization of Sterilization of Rambutan} Leaf Explants

Rambutan leaves are washed under running water, add $70 \%$ alcohol solution for 1 minute and soak in $2 \%$ sodium hypochlorite (Bayclin) solution for 1 minute. Rinse with sterile water for three repetitions.

\section{Induction Callus}

Callus culture initiation was carried out using rambutan leaves planted on MS and WPM base media with addition (Indole-3 Butyric acid) and kinetin as a growth regulator used in various concentrations to initiate callus culture. Explants were cut to a size of $1 \times 1 \mathrm{~cm}$ and planted on the media with various growth regulators. Callus growth was observed every day.

\section{Callus Extraction}

Rambutan leaf extract was carried out by cold extraction method, namely maceration by sonification using multilevel solvents including n-hexane, ethyl acetate, and ethanol. Several dried crude drug results from tissue culture were put into a vial, added n-hexane solvent to all submerged. Then left for 20 minutes. The filtrate is filtered, and the residue is remunerated with ethyl acetate until submerged and treated as nhexane. The resulting filtrate was remacerated with ethanoluntil it was submerged and filtered. 


\section{Rambutan (Wild Type) Extraction}

The manufacture of rambutan leaf extract was carried out using the cold extraction method using multilevel solvents including $n$-hexane, ethyl acetate, and ethanol. 20 grams of crude drugs were added $100 \mathrm{~mL}$ of $n$-hexane solvent to all submerged. Then left for 24 hours. The filtrate is filtered, residue demineralized with $100 \mathrm{~mL}$ ethyl acetate, and treated asn-hexane. Theresulting filtrate was remacerated with $100 \mathrm{~mL}$ of ethanol and filtered.

\section{Analysis of Secondary Metabolites with Thin Layer Chromatography (TLC)}

Identification of secondary metabolite content callus is dissolved in the original solvent, then it is sprayed on silica gel plate GF254 with a size of 10x1 cmand used mobilephase Toluene:Acetone and mobile phase Ethyl Acetate: n-hexane with a ratio of 7: 3 and saturated in a closed vessel for 30 minutes. The plate is then inserted into the vessel to elute with the mobile phase above to the limit that has been determined on the silicaplate. Identifying the content is carried outgives a specific spot appearance for each class of secondarymetabolites.

\section{Result And Discussion}

\section{Rambutan Leaf Tissue Culture}

The initial stages of tissue culture are sterilization optimization with the treatment of immersion

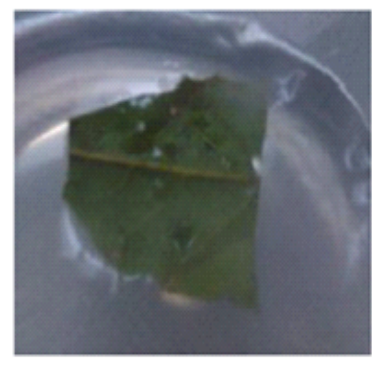

a

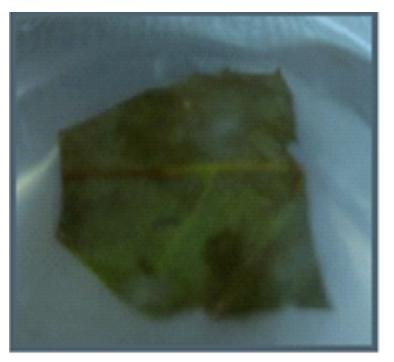

b

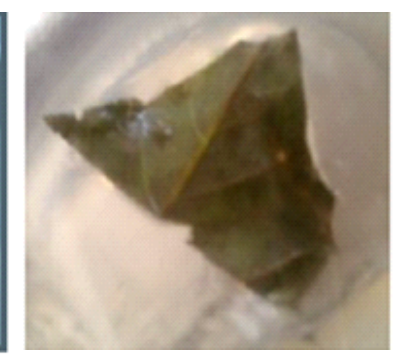

c time variation in hypochlorite. Various variations, explant sterilization, carried out, obtained $70 \%$ alcohol's best sterilization for 1 minute and $2.5 \%$ hypochlorite for 7 minutes. The best sterilization method is characterized by low levels of contamination and high levels of freshness network so that this sterilization method can be used in the next sterilization. Pierik (1987) argues that to stimulate callus formation from plant tissue pieces on artificial medium, growth-regulating agents are needed auxins and cytokines (Pierik, 1997). In this study, callus was obtained from the results of planting explants of leaves of Nepheliumlappaceum L. in Murashige and Skoog dense medium (MS) The leaves roll in the medium Woody plant medium (WPM), which is equipped with IBA-Kinetin Growth Regulatory Substances and the media without the addition of Growth Regulatory Substances as a control on bothmediums. There are differences in the results of observations on tissue culture of rambutan leaf explants planted on MS media and WPM media. Callus appears on the medium MS, whereas in WPM, media explants provide a response in the form of rolling, do not grow callus (Figure 1 and Figure 2).

Callus appears on the surface of leaf explants from injury, characterized by enlargement of explant size and spots yellow. On MS media, callus starts to appear seven days after explants

Figure 1. The beginning of planting, the color of the leaves is still green (a), the first week, the current part brown leaves (b), the second week leaf surface brown (c), the fourth week, leaf surface brown (d) 
are cultured (Figure 3).4; days after the implant is cultured, the WPM media leaves change by rolling up (Figure 4). Indole-3-Butyric Acid (IBA) at a concentration of $2 \mathrm{mg} / \mathrm{L}$ and kinetin $3 \mathrm{mg} / \mathrm{L}$ can stimulate leaf cell division and process differentiation to form a callus. Following what was stated by Smith (1992), IBA, which belongs to the auxin group in a

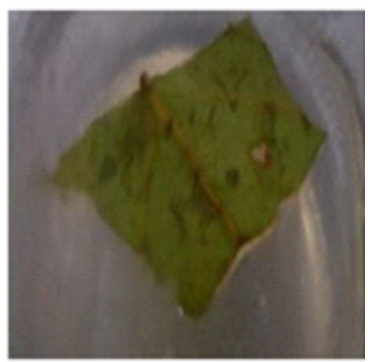

a

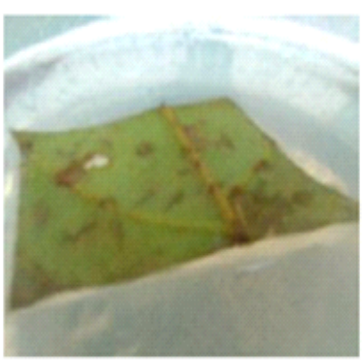

b

concentration high, will stimulate callus formation and suppress morphogenesis (Smith, 1992). In addition to that, kinetin's presence at a concentration of $3 \mathrm{mg} / \mathrm{L}$ in the supporting medium callus formation. This is supported by Setiti et al. (1996)suggested that the media with cytokines would increase callus the proliferation (Setiti et al., 1996).

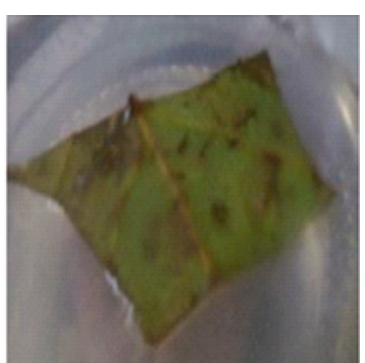

c

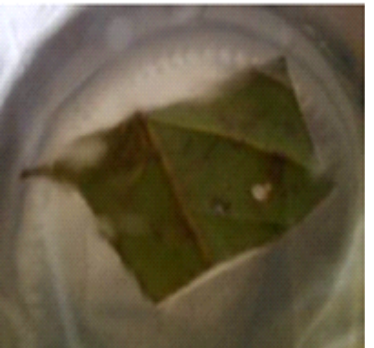

d

Figure 2. The beginning of planting, the color of the leaves is still green (a), the first week the current part brown leaves (b), the second week no changes in leaves (c) the fourth week, leaf surface brown (d).

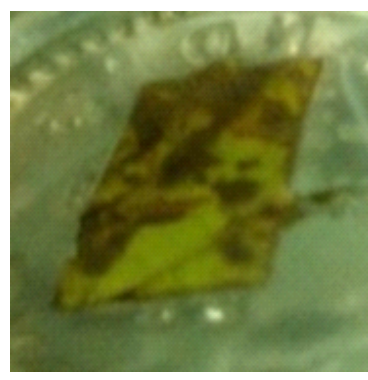

a

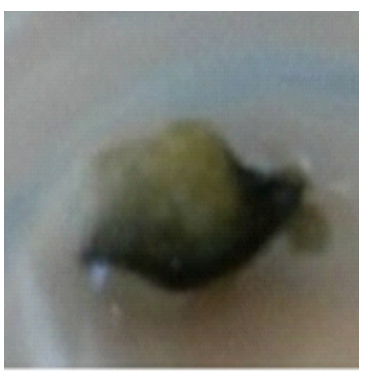

b

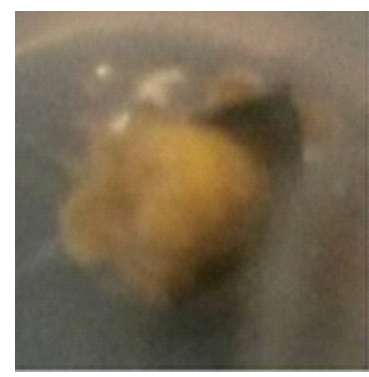

C

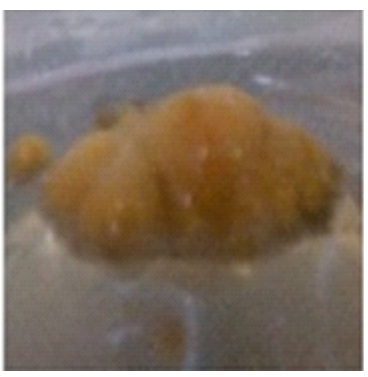

d

Figure 3 Rambutan leaves in murashige and Skoog Media with growth regulator IBA: Kinetin (2: 3). (a): the beginning of planting, brown leaf color, (b) the first week, the edge of the leaf is slightly raised, (c) the fourth week, a yellow callus is formed, (d) the six weeks, callus forme

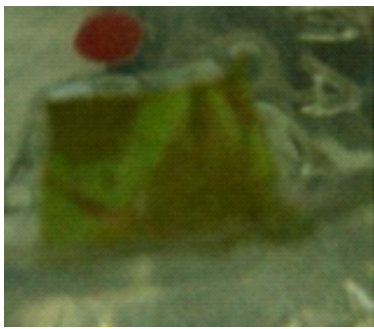

a

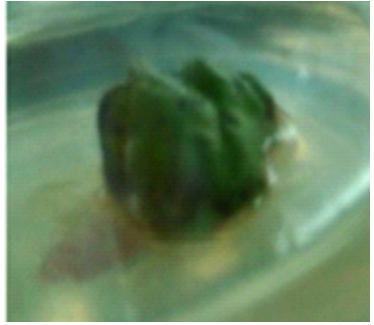

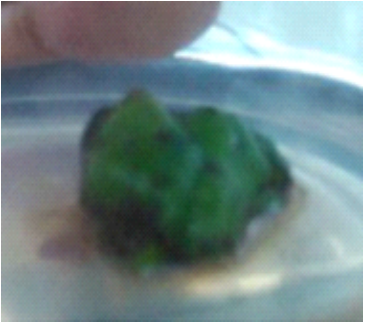

C

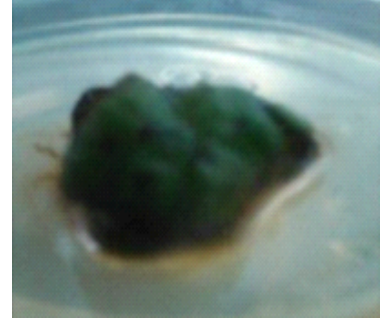

d

Figure 4 Rambutan leaves in Woody Plant Medium (WPM) media with growth regulator IBA: Kinetin (2: 3). the beginning of planting, the shape is still flat and green (a), the first week, the section is sliced brown and the leaves roll (b), the fourth week, leaves roll up (c), the six weeks, the color of the leaves becomes dark green $(\mathrm{d})$ 
A callus that grows relatively quickly appears because on the 7 th day after being cultured has been formed. This is because the exogenous growth regulating substances in the formof auxin and cytokines are also due to injury to explants. The callus is the mass proliferation of networks that have not been differentiated so that they are increasingly widespread the surface of the explant slices is more and more callus formed (Hendaryono et al., 1994). There are differences in the results of tissue culture in both possible media caused by different media content. Of the two types of media, it turns out that there is a tendency for changes to the fastest explants that are rolling on the 4th day after the leaves are cultured, namely the WPM media (Woody Plant Medium) although this media is unable to grow callus as in MS media. This is thought to be the nutrient content in WPM media optimized by explants to roll. Other than that, WPM media is a medium commonly used in tissue culture various types of woody plants. WPM media is widely used in various woody plant species because it has a low total ion content but high sulfate content. Macroelements in WPM media, such as high magnesium elements, support tissue growth plants (Pardal et al., 2004). The media must also contain minerals, sugar, vitamins, and hormones with precisely the required ratio (Wetherell, 1982). Allegedly media The WPM has enough nutrients for rolling explants. While the MS medium specialty is nitrate, potassium, and high ammonium, and the amount of inorganic nutrients suitable for meeting the needs of many plant cells in culture, callus formation is possible (Wetter et al., 1991). In media without the addition ofZPT or control, it does not show changes on leaf explants. The rambutan allegedly causes these leaves to be cultured, which requires exogenous ZPT to form callus even though the leaves themselves already have endogenous auxin, but not enoughto forma callus.

\section{Analysis of secondary metabolites with Thin Layer Chromatography (TLC)}

Extract from rambutan leaves nonculture and callus obtained monitoring using thin-layer chromatography. The motion phase eluted all three, namelyn-hexane: ethyl acetate (3: 7) and toluene: acetone 7:3. The profile of TLC obtained, compared, and is broken with the appearance of specific spots. The TLC profile generated between rambutan leaves without tissue culture, rambutan leaves tissue culture, and callus provides different TLC profiles. In tissue culture leaves with the mobile phase Toluene-Acetone, there are spots bright blue after being sprayed with $10 \% \mathrm{H}_{2} \mathrm{SO} 4$, spotting methanol and heating the plate. The heating process will evaporate the solvent and detect organic compounds marked by changes in color after heating. The bright blue spots have $\mathrm{Rf}$ values of 0.3 and 0.5 .

The chromatogram observation that has been sprayed shows the appearance of citroborate spots shows lighter spots on UV $365 \mathrm{~nm}$ with an Rf value of $0.34 ; 051 ; 0.56$. Flavonoids are yellow, greenish-yellow, and spots reddishyellow under UV light $366 \mathrm{~nm}$, at Rf: $0.3 ; 0.7$; and 0.8 with detection of Sitroborat (Figure 5) (Markham, 1982).

Whereas in the callus, the measured $\mathrm{Rf}$ value is 0.18 with no spotting too bright, this is the possibility of secondary metabolites found in callus it is not eluted well by the mobile phase used. In the mobile phase of n-hexane- ethyl acetate, bright blue spots with an $\mathrm{Rf}$ value of 0.66 and 0.82 and yellow spots with an $R f$ value of 0.73 (Figure 6). 


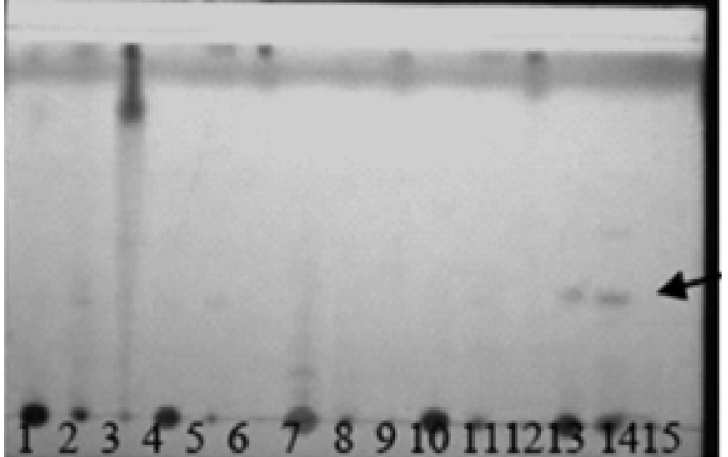

A

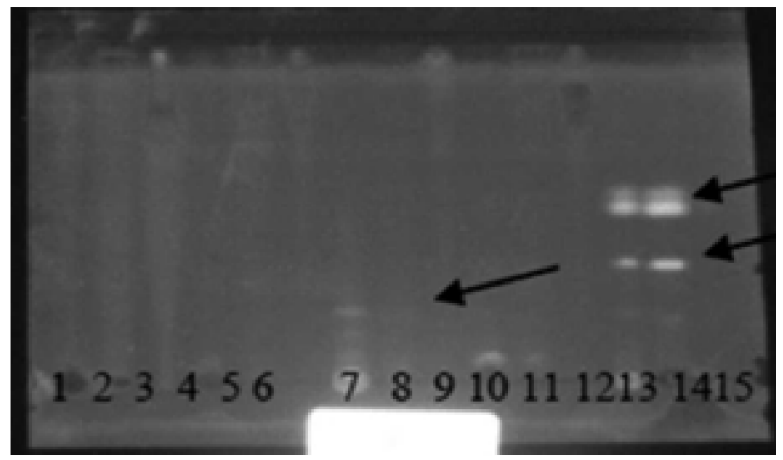

B

Figure 5 Thin-layer chromatography callus and leaf extract rambutan with toluene: acetone (7:3) mobile phase with the appearance spots of citroborate. Observed under $254 \mathrm{~nm}$ Uv Light (A), Observed under 365 nm Uv light (B), Ethanol extract of rambutan leaves (1), Ethyl Acetate Extract of rambutan leaves (2), n-hexane extract of rambutan leaves (3), Ethanol extract of rambutan leaf control on Murashige\&Skoog media (4), Ethyl acetate extract control of rambutan leaves on Murashige\&Skoog media (5), N-hexane extract control of rambutan leaves on Murashige\&Skoog media (6), Callus Ethanol Extract in Murashige\&Skoog media (7), Ethyl acetate callus extract in Murashige\&Skoog media (8), N-hexane extract of Callus in Murashige\&Skoog media (9), Ethanol extract controls rambutan leaves on the Woddy Plant media (10), Ektrak Ethyl acetate controls rambutan leaves on the Woddy Plant media (11), The n-hexane extract controls the rambutan leaves on the Woddy Plant media (12), Explanation of Ethanol Extract in the Woddy Plant media (13), Ethyl acetate extract Explants in the Woddy Plant media (14) and Extract of n-hexane Eksplan in the Woddy Plant media (15).

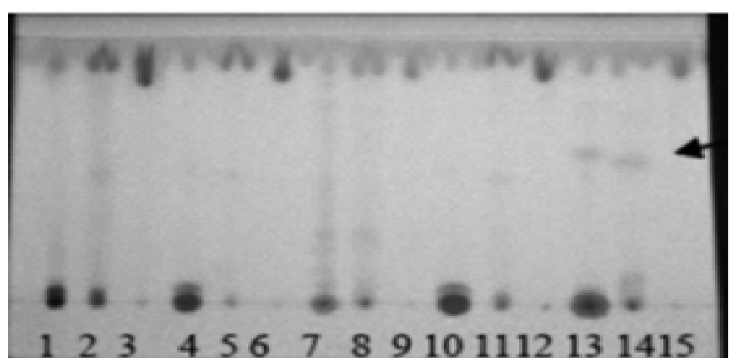

A

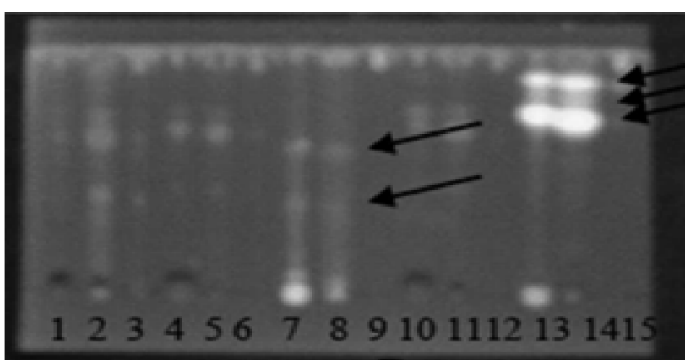

B

Figure 6 Thin-layer chromatography callus and leaf extract rambutan with n-hexane: ethyl acetate (3:7) mobile phase. Observed under $254 \mathrm{~nm}$ Uv Light (A), Observed under $365 \mathrm{~nm}$ Uv light (B),

Examination of triterpenoids (steroids) using Libermann color reagents Burchard, if there are triterpenoid compounds (steroids) after LB and heated at a temperature of $100^{\circ} \mathrm{C}$ for $5-10$ minutes, it will show spots orange-yellow (Figure 7) (Wagner, 1984). The presence of flavonoid compounds is indicated by spotting yellow-green or bright blue on UV-354 nm with a range of Rf values 0.2-0.8, compound is suspected a flavonoid (Figure 8). At the result of the chromatogram, the rambutan leaves a result from the cut tissue with a mobile phase Toluene-Acetone shows the presence of colored spots yellow with $\mathrm{Rf}$ values of 0.53 0.81 in the mobile phase of n-hexane-ethyl acetate. While in callus, there is also the appearance of blue spots with an aRf value of 0.52 . Sitroborat spray reagent is used to detect flavonoids. 


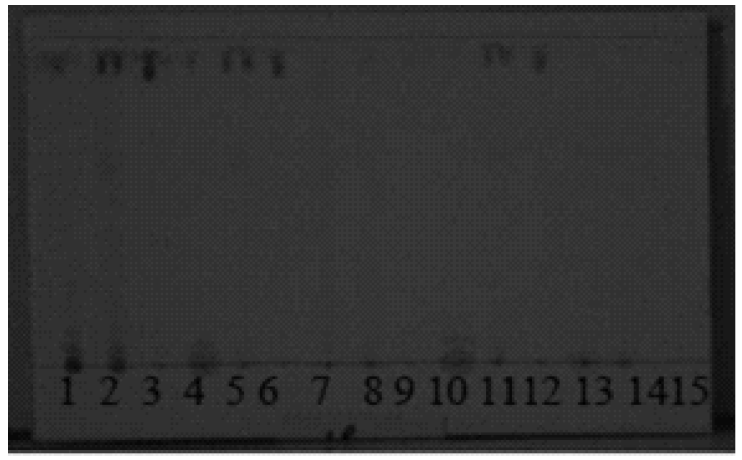

A

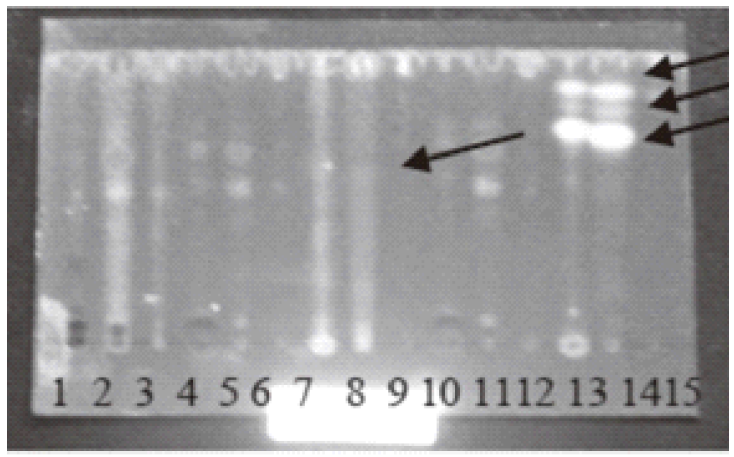

B

Figure 7 Thin-layer chromatography callus and leaf extract rambutan with n-hexane: ethyl acetate (3:7) mobile phase with the appearance spots of Lieberman Burchard. Visual (A), Observed under $365 \mathrm{~nm}$ Uv light (B).
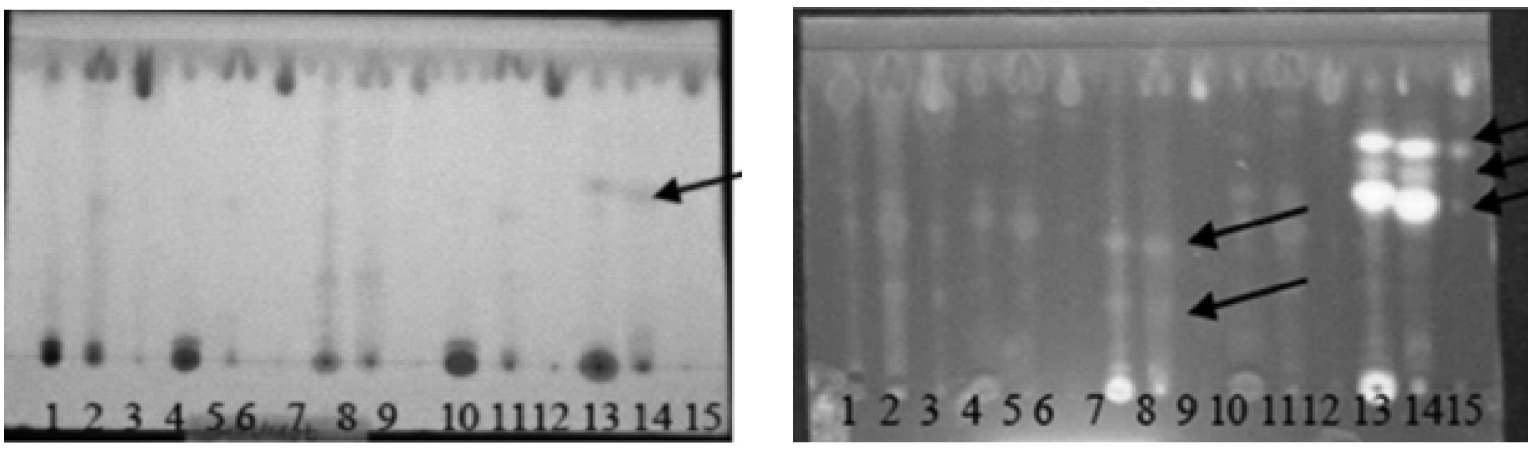

Figure 8 Thin-layer chromatography callus and leaf extract rambutan with n-hexane: ethyl acetate (3:7) mobile phase with the appearance spots of citroborate. Observed under $254 \mathrm{~nm}$ Uv Light (A), Observed under $365 \mathrm{~nm}$ Uv light (B),

\section{Conclusion}

The best optimization results of rambutan leaf sterilization are deep immersion 70\% 1-minute alcohol and $2.5 \%$ hypochlorite for 5 minutes are indicated a low level of contamination. There are differences in the intermediate tissue culture Murashige and Skoog (MS) media and Woody plant medium(WPM). In the media, MS can produce callus while the WPM cannot produce callus or shoot yet. However, rambutan leaves show a growth response in the form of the leaves or explants is curled. Both media are equipped with Regulating Substances. The same growth is IBA-Kinetin (2:3). The difference in the media composition is suspected of causing differences in response to rambutan leaves' development. Analysis of secondary metabolites content of rambutan leaf tissue culture is with Thin Layer Chromatography. The mobile phase used is Toluene-Acetone (7:3) and n-hexaneEthylAcetate (3:7), observing the TLC results from the leaves rambutan resulting from tissue culture is thought to contain flavonoid and triterpenoid Compounds.

\section{Acknowledgments}

Institute for Research and Community Service Universitas JenderalAchmad Yani

\section{Reference}

Abidin, Zainal. 1993. Knowledge Basics About Growing Regulatory Substances. Bandung: Space. p. 1, 44. 
Chen HS, Bai MH, Zhang T, Li GD, Liu M. 2015. Ellagic acid induces cell cycle arrestand apoptosis through TGF- $\beta$ / Smad3 signaling pathway in human breast cancer MCF-7cells, Int J Oncol.; 46 (4): 1730-8.

Cronquist, A. 1981. An Integrated System of Clasification of Flowering Plants. New York: Columbia University Press. Page. 795-797.

Dalimarta, S. 2003. Atlas of Indonesian Medicinal Plants, volume 3. Jakarta: Puspa Swara. Page. 116.

Gambari R, Hau DK, Wong WY, Chui CH, 2014. Sensitization of Hep3B hepatoma cellsto cisplatin and doxorubicin by corilagin. Phytother Res, 28 (5): 781-3.

Hariana, A., 2006. Medicinal Plants and Their Benefits, Series 3, Penebar Swadaya, Jakarta.

Hendaryono, Sriyanti P Daisy, Ari Wijayani. 1994. Tissue Culture Techniques; Introduction and Vegetative Modern Plant propagation instructions. Yogyakarta: Kanisius. Hal. 26-28, 17.

Jia L, Jin H, Zhou J, Chen L, Lu Y, Ming Y, Yu Y. 2013. A potential herbal antitumormedicine, Corilagin, ovarian cancer cell growth through blocking the TGF-ßsignaling pathways. BMC Complement Altern Med.

Kashiwada Y, Nonaka G, Nishioka I, Chang JJ, Lee KH. 1992. Tannins and related compounds as selective cytotoxic agents. Antitumor agents, J Nat Prod; 55 (8): 1033-43.
Li J, Wang S, Yin J, Pan L. 2013. Geraniin induces apoptotic cell death in human lungadenocarcinoma A549 cells in vitro and in vivo. Can J Physiol Pharmacol; 91 (12): 1016-24.

Losso JN, Bansode RR, TrappeyA2nd, Bawadi HA, Truax R. 2004 Nov. In vitro antiproliferativeactivities of ellagic acid. $\mathrm{J}$ Nutr Biochem ; 15 (11): 672-8.

Markham, K.R.1982. Cara Mengidentifikasi Flavonoid, diterjemahkan oleh Kosasih Padmawinata. Bandung: Penerbit ITB.

Okabe S, Suganuma M, Imayoshi Y, Taniguchi S, Yoshida T, Fujiki H. 2001. New TNFalphareleasing inhibitors, geraniin and corilagin, in leaves of Acernikoense, Megusurino-ki. Biol Pharm Bull. t; 24 (10): 1145-8.

Pardal, S. J., Ika, M., E. G. Lestari., dan Slamet. 2004. Regenerasi Tanaman dan Transformasi Genetik Salak Pondoh untuk Rekayasa Buah partenokarpi. J. BioteknologiPertanian.

Pierik, R.L.M. 1997. In vitro Culture of Higher Plants. The Netherlands: Kluwer Academic Publisher, Dordrect. p. 90-91.

Ria, Johny. 1994. Indonesian Medicinal Plant Inventory (III). Jakarta: AgencyResearch and Health movement phases.

Setiti, E.W.U., Sri Puji A.W. and T. Sudarti. 1996. The role of the media and ZPT forcallus induction and differentiation in melon tissue cultivation. Journal Horticulture.

Smith, R.H. 1992. Plant Tissue Culture: Technique and Experiments. New York: Academic Press Inc. 
StratiA, Papoutsi Z, Lianidou E, Moutsatsou P. 2009. Effect of ellagic acid on theexpression of human telomerase reverse transcriptas (hTERT) alpha + beta + transcript inestrogen receptorpositive MCF-7 breast cancer cells. Clin Biochem ; 42 (13-14): 1358-62.

Thitilertdecha, N, Teerawutgulrag, A, Jeremy D. Kilburn and Rakariyatham. N. 2010. Identification of Major Phenolic Compounds from Nephelium lappaceum L. and TheirAntioxidant Activities, Molecules, 15, 1453-1465.

Wagner H., Bladt S., ZgainskiE.M. 1984. Plant Drug Analysis: A Thin Layer Chromatography Atlas. New York: Springer-Verlag.
Wetherell, D. F. 1982. Pengantar Propagasi Tanaman secara In Vitro Seri Kultur Jaringan Tanaman. New Jersey: Avery Publishing Group.

Wetter, L. R., dan F. Constabel. 1991. Metode Kultur Jaringan Tanaman. Bandung: ITB.

Zhang T, Chen HS, Wang LF, Bai MH, Wang YC, Jiang XF, Liu M. 2014. Ellagic acidAnti-proliferation effects exerts via modulation of Tgf- $\beta$ / Smad3 signaling in MCF-7breast cancer cells. Asian Pac J Cancer Prev. (1): 273-6.

Zulkarnain. 2009. Plant Tissue Culture. Jakarta: Bumi Aksara. Hal. 38-40, 9394, 111, 112, 98-99, 100-101,161-162. 